Research Paper

\title{
Mucorales from the semiarid of Pernambuco, Brazil
}

\author{
André Luiz Cabral Monteiro de Azevedo Santiago ${ }^{1,3}$, Paulo Jorge Parreira dos Santos ${ }^{2}$, \\ Leonor Costa Maia ${ }^{3}$ \\ ${ }^{1}$ Unidade Acadêmica de Serra Talhada, Universidade Federal Rural de Pernambuco, \\ Serra Talhada, PE, Brazil. \\ ${ }^{2}$ Departamento de Zoologia, Centro de Ciências Biológicas, Universidade Federal de Pernambuco, \\ Recife, PE, Brazil. \\ ${ }^{3}$ Programa de Pós-graduação em Biologia de Fungos, Universidade Federal de Pernambuco, \\ Recife, PE, Brazil.
}

Submitted: August 8, 2011; Approved: July 2, 2012.

\begin{abstract}
Nineteen taxa of Mucorales, belonging to Absidia, Apophysomyces, Cunninghamella, Fennellomyces, Lichtheimia, Mucor, Mycotypha, Rhizopus and Syncephalastrum were isolated from 36 composite soil samples in three semiarid areas in the State of Pernambuco (Triunfo, Cabrobó and Belém de São Francisco), Northeast Brazil, which are characterized by Caatinga vegetation. Triunfo is preserved, whereas Cabroró and Belém de São Francisco are experiencing low and severe desertification processes, respectively. Mucorales were isolated in Petri dishes in triplicate from $5 \mathrm{mg} \mathrm{sam}-$ ples of soil placed on the surface of wheat germ agar plus chloramphenicol and Cercobin [Dimethyl 4,49-(103 phenylene) bis (3-thioallophanate)] medium. The plates were left on a bench at room temperature $\left(28 \pm 2{ }^{\circ} \mathrm{C}\right)$ for $72 \mathrm{~h}$ of alternating dark and light periods. Absidia cylindrospora presented the highest amount of CFU/g of soil, followed by L. hyalospora, C. phaeospora and C. echinulata var. echinulata. The latter, and $R$. microsporus var. microsporus, presented the highest frequencies of occurrence. Soils from Triunfo showed higher diversity of Mucorales than the samples from the other areas, although without differing statistically in relation to species richness. The communities of Mucorales from the degraded areas were more similar, while that from the preserved area was quite different. Most of the identified specimens have been commonly isolated from soil in other Brazilian regions, which indicates that they are not endemic of the semiarid. Eleven taxa are registered for the first time in this ecosystem, while $F$. heterothallicus is reported for the first time in Brazil.
\end{abstract}

Key words: biodiversity, Caatinga, Mucoromycotina, soil degradation, taxonomy.

\section{Introduction}

The Mucorales is the largest order of the traditional Zygomycota (a phylum not accepted in the new classification since it is polyphyletic), and today is classified among the Mucoromycotina (Hibbett et al., 2007), a subphylum of fungi with 325 known species (Kirk et al., 2008), from which 90 are registered in Brazil (Santiago, 2012). These fungi are characterized by the production, during sexual reproduction, of zygospores, which are thick-walled pigmented spores, in general resistant to stressful conditions. More often these fungi reproduce asexually, forming small, hyaline, sporangiospores which are also responsible for species dissemination. The Mucorales can be easily isolated from soil, dung, water, stored grains, plants, and even from other fungi, including zygomycetes (Benny, 2009). Although living as saprobes in most ecosystems, Mucorales parasites have also been described. Some species have been reported as agents of systemic infections in humans, especially in immunocompromised patients (Ribes et al., 2000) and others cause diseases in plants and seeds (Riccardi and Bashore, 2003) and decay of fruit, stored grains and other cereals (Hesseltine and Fennel, 
1995). Beneficial species are traditionally used in the production of fermented foods in Asia (Nout and Kiers, 2005). Species of Cunninghamella, Mucor and Rhizopus are able to produce metabolites such as amylase, lipase, inulinase, pectinase, renin and protease (Alves et al., 2002; Santiago and Souza-Motta, 2006) as well as citric, linolenic, arachidonic, oxalic and lactic acids (Yin et al., 1998; Zhou et al., 1999; Magnuson and Lasure, 2004). Studies of the role of Mucorales in the bioremediation of heavy metals (Zafar et al., 2007), and in biologic control (Wekesa et al., 2007), have been also carried out.

Knowledge of the diversity of Mucorales is precarious and fragmented, especially in mega-diverse countries such as Brazil, where rapid environmental changes make biota recognition a more urgent issue. In Brazil, this group of fungi has mainly been studied in the States of Bahia, Maranhão, Pernambuco and São Paulo (Upadhyay, 1969; Lira, 1971; Viriato and Trufem, 1985; Alves et al., 2002; Santiago and Souza-Motta, 2006), and only 13 species were reported in the semiarid regions of Brazil (Santiago, 2012). This does not reflect the real richness of these regions, which are practically unexplored as regards fungi.

Desertification is defined by the United Nations Convention to Combat Desertification (UNCCD) as "land degradation in arid, semiarid and dry sub-humid areas, resulting from various factors, including climatic variations and human activities". A series of data is required to characterize the desertification process (Sampaio et al., 2003) and in the Northeast of Brazil, although data are still scarce, the Ministry of Environment recognizes four nuclei of desertification, one of which is located in the State of Pernambuco and comprises the Municipalities of Cabrobó, Floresta and Belém de São Francisco. Knowledge of the mycota in these areas is important since these microorganisms have been used as indicators of environmental changes and are key components of the microbiota, contributing for the maintenance of ecosystems (Turco et al., 1994).

Considering the ecological importance and the insufficient data about the Mucorales, the aims of this study were: to study the diversity and distribution of the group in three semiarid areas (preserved, under low and severe desertification processes); to determine the similarity of species composition among the studied areas; to evaluate the communities of Mucorales using quantitative and qualitative population data (frequency of occurrence and relative abundance) and through ecological indexes (richness and diversity), and to discuss the influence of the desertification process on the community of Mucorales in the studied areas.

\section{Materials and Methods}

\section{Studied areas}

Soil samples were collected in Belém de São Francisco (38 $8^{\circ} 2^{\prime} 70^{\prime \prime} \mathrm{W}, 8^{\circ} 71^{\prime} 93^{\prime \prime}$ S, 305 m alt., - Caatinga un- dergoing severe desertification), Cabrobó (39 $21^{\circ} 02^{\prime \prime} \mathrm{W}$, $8^{\circ} 35^{\prime} 82^{\prime \prime} \mathrm{S}, 325 \mathrm{~m}$ alt., - Caatinga with a low degree of desertification) and Triunfo ( $38^{\circ} 06^{\prime} 03^{\prime \prime}$ W, $7^{\circ} 52^{\prime} 28^{\prime \prime}$ ' S, $650 \mathrm{~m}$ alt., - area of preserved Caatinga) located in Pernambuco State, Northeastern Brazil. The cities of Belém de São Francisco and Cabrobó fall within the environmental unit of semiarid depression. The vegetation is primarily composed of hyper-xerophilous savanna with patches of deciduous forest. The climate is tropical and semiarid with summer rains. The rainy season is from November to April. The average annual precipitation is $431.8 \mathrm{~mm}$ (Ministério das Minas e Energia, 2005a, 2005b). The entire city of Triunfo is within the hydrographic basin of Pajeú, a region predominantly forested with sub-deciduous vegetation. According to Ferraz et al. (1998), in Triunfo the area of higher altitude $(1100 \mathrm{~m})$ is occupied by a vegetation of upland forests, whereas the areas of lower altitudes (500 to $700 \mathrm{~m}$ ) are characterized by Caatinga vegetation. At $900 \mathrm{~m}$ alt. the vegetation shows elements of upland forests with Caatinga. The climate, according to the Koppen classification, is hot and humid, with an average annual temperature of $25^{\circ} \mathrm{C}$. The rate of annual rainfall is $1222 \mathrm{~mm}$, with a dry period of seven months and rainfall concentrated in March and April (Ministério das Minas e Energia, 2005c).

\section{Soil collections}

Soil samples were collected in Cabrobó, Triunfo and Belém de São Francisco during dry (November) and wet (March) periods, as follows: [November/2008: Cabrobó $(11 / 24 / 2008=0.0 \mathrm{~mm}$ precipitation during all month); Belém de São Francisco $(11 / 25 / 2008=0.0 \mathrm{~mm}$ precipitation during all month); and Triunfo $(11 / 26 / 2008=6.8 \mathrm{~mm}$ during all month and $4.8 \mathrm{~mm}$ precipitation during the seven days that preceded the collection)], [March/2009: Cabrobó $(03 / 19 / 2009=108.5 \mathrm{~mm}$ precipitation during all month and $62.8 \mathrm{~mm}$ during the seven days that preceded the collection); Belém de São Francisco (03/22/2009 = 35 mm precipitation during all month and $19.6 \mathrm{~mm}$ during the seven days before collection); and Triunfo $(03 / 20 / 2009=134.5$ $\mathrm{mm}$ during all month and $32.9 \mathrm{~mm}$ during the seven days before collection)]; [November/2009: Cabrobó $(11 / 11 / 2009=0.0 \mathrm{~mm}$ precipitation during all month); Belém de São Francisco (11/12/2009 = $8.2 \mathrm{~mm}$ precipitation during all month and $1.4 \mathrm{~mm}$ during the seven days before collection); Triunfo $(11 / 13 / 2009=0.0 \mathrm{~mm}$ precipitation during all month)] (www.inmet.com.br). Soil samples taken in November/2008 and November/2009 were dry, and the weather was hot, with clear sky, and no rain on the day of collection; soil samples collected in March/2009 from Cabrobó and Triunfo were moist, and the leaves on the trees were green, although it was not raining during the collection day; samples collected in Belém de São Franscisco were dry, and the leaves on the trees were dry or absent. 
Each area was divided in two sectors of $500 \mathrm{~m}^{2}$ and in each sector ten collection points were chosen. The first one was chosen randomly and the other points were located at least $10 \mathrm{~m}$ apart from the previous one, maintaining a random design. At each point, using sterilized spatulas, three subsamples of $15 \mathrm{~g}$ portions of soil were collected to $10 \mathrm{~cm}$ depth, mixed and placed in new, clean, plastic bags, forming one composite sample stored in polystyrene boxes containing ice bags. From the 180 subsamples, 36 composite samples (108 Petri plates) were made by combining two sets of five subsamples each, from each of the two areas of the three sites, for each of the three collections. Thus at each area ten samples were collected per sector, or twenty from each area (total of 180 soil samples, considering the three collections at the three Caatinga sampling areas).

\section{Isolation of the Mucorales}

For each one of the 36 samples, three $5 \mathrm{mg}$ subsamples of soil particles were placed on the surface of wheat germ agar (Benny, 2008) plus chloramphenicol $(80 \mathrm{mg} / \mathrm{L})$ and Cercobin [Dimethyl 4,49-(O-phenylene) bis (3-thioallophanate)] (4 mg/L) in Petri dishes, according to Ho (2002), modified. The Petri dishes were left on a bench at room temperature $\left(28 \pm 2{ }^{\circ} \mathrm{C}\right)$ for $72 \mathrm{~h}$ of alternating light and dark periods and observed in a stereomicroscope (Carl Zeiss Axioscope 40) and a light microscope (Leika EZ4). Fragments of colonies were transferred to the surface of $\mathrm{M}$ agar (malt extract $20 \mathrm{~g}$, glucose $20 \mathrm{~g}$, peptone $1 \mathrm{~g}$, agar $15 \mathrm{~g}$, distilled water $1000 \mathrm{~mL}, \mathrm{pH}=6.0)\left(\mathrm{O}^{\prime}\right.$ Donnell, 1979) plus chloramphenicol $(80 \mathrm{mg} / \mathrm{L})$. After the isolation and purification of cultures the fungi were identified based on macroscopic (color, aspect and diameter of the colonies) and microscopic (microstructures) characters according to Schipper (1978), Misra and Lata (1979), Schipper and Samson (1994), Hesseltine and Fennel (1995), Zheng and Chen (2001), Zheng et al. (2007) and Alastruey-Izquierdo et al. (2010). Mucorales communities were evaluated qualitatively and quantitatively using data from the population (frequency of occurrence and relative abundance), and its structure analyzed by ecological indices (richness and diversity). Frequency of occurrence (Fi) was calculated according to the following equation: $\mathrm{Fi}=\mathrm{Ji} / \mathrm{k}$, where $\mathrm{Fi}=$ frequency of occurrence of the species $\mathrm{i} ; \mathrm{Ji}=$ number of samples in which the species $\mathrm{i}$ has occurred; $\mathrm{k}=$ total number of soil samples (Brower et al., 1990).

Relative abundance of each species within the three studied areas was evaluated according to the following equation: $\mathrm{Ra}=(\mathrm{Ni} / \mathrm{N}) \times 100$, where $\mathrm{Ra}=$ relative abundance of the species $\mathrm{i}$; $\mathrm{Ni}=$ number of $\mathrm{CFU}$ of the species $\mathrm{i}$; $\mathrm{N}=$ total number of CFU of fungi in all samples, in each area). According to this formula, each taxon can be classified as: $\mathrm{Ra}<0.5 \%=$ rare; $0.5 \leq \mathrm{Ra}<1.5 \%=$ occasional; $1.5 \leq \mathrm{Ra}<3.0 \%=$ common; $\mathrm{Ra}>3.0 \%=$ abundant (Schnittler and Stephenson, 2000, modified).
The Shannon-Wiener index was used to estimate the diversity of Mucorales in the areas studied, according to Peet (1974). Chaol and Jacknifel richness estimators as available in Primer 5.2.4 (Clarke and Warwick, 1994) were applied to the data in order to evaluate the completeness of the survey. The similarity of the species between the sampling sites was estimated by the Sorensen index, using the equation: $\mathrm{S}=(2 \mathrm{c} / \mathrm{a}+\mathrm{b}) \times 100$, where $\mathrm{c}=$ number of species common to both areas; $\mathrm{a}=$ number of species from area 1 ; $\mathrm{b}=$ number of species from area 2 (Sorensen, 1978).

\section{Statistical analysis}

Differences in the communities of Mucorales species among different areas were analyzed using Analysis of Similarity (ANOSIM Primer 5.2.4) (Clarke and Warwick, 1994). Differences in species richness among the three areas were evaluated by the ANOVA like non-parametric Kruskal-Wallis test (Zar, 1996).

\section{Results}

Altogether, 17 species and six varieties of Mucorales $\left(9.3 \times 10^{4} \mathrm{CFU} / \mathrm{g}\right.$ of soil) were isolated from the soil samples; ten taxa distributed in six genera were isolated from the soil of Belém de São Francisco; 11 taxa where obtained from samples collected in Cabrobó, and eight taxa were isolated from Triunfo's soil (Table 1).

Absidia cylindrospora var. cylindrospora presented the highest number of CFU/g of soil (3.16 x 10 $0^{4}$ ), followed by Lichtheimia hyalospora $\left(1.36 \times 10^{4}\right)$, C. phaeospora and C. echinulata var. echinulata $\left(1.12 \times 10^{4}\right)$. More colonies of Mucorales $\left(6.84 \times 10^{4}\right)$ were registered in the soil of the preserved area than in that of the degraded areas (Belém de São Francisco $=1.64 \times 10^{4}$ and Cabrobó $\left.=8.2 \times 10^{3}\right)($ Table 1$)$. Only L. hyalospora $(\mathrm{Di}=3.46 \%)$ can be considered abundant, while $C$. echinulata var. echinulata and $C$. phaeospora $(2.77 \%)$ were quite common. Absidia cylindrospora var. cylindrospora (1.04\%), R. arrhizus var. arrhizus $(0.89 \%)$ and and $R$. microsporus var. microsporus $(0.57 \%)$ were occasional. All other taxa were rare. Rhizopus microsporus var. microsporus (10.19\%) and C. echinulata var. echinulata $(9.26 \%)$ were the most frequent in the three areas, followed by $A$. cylindrospora and $R$. arrhizus var. arrhizus (7.41\%). The other taxa showed a low $(<5 \%)$ frequency of occurrence (Table 2$)$.

Chaol richness estimator indicates an expected richness of $21.7( \pm 3.5)$ and the Jacknife1 method estimates 27.9 taxa for the combined data of the sampling area. The diversity of Mucorales was higher in Triunfo $(\mathrm{H} 1=2.85)$, followed by Cabrobó $(\mathrm{H} 1=2.73)$ and Belém de São Francisco $(H 1=2.13)$. The differences in species richness among the three areas were not significant [(p) KruskalWallis $=0.854 ; \mathrm{H}=03157 ; \mathrm{G} . \mathrm{L}=2]$. Species similarity was higher between samples collected in Belém de São Francisco and Cabrobó (66.7\%), which differs from what was 
Table 1 - Number (CFU/g) and species richness of Mucorales in soils from three semiarid areas of Pernambuco (Triunfo, Cabrobó and Belém de São Francisco)

\begin{tabular}{|c|c|c|c|c|}
\hline Mucorales & Triunfo (PC) & Cabrobó (LDD) & $\mathrm{BSF}(\mathrm{SD})$ & Total \\
\hline Absidia cylindrospora var. cylindrospora Hagem & $3.16 \times 10^{4}$ & - & - & $3.16 \times 10^{4}$ \\
\hline Apophysomyces elegans P.C. Misra, K.J. Srivast. \& Lata & - & $4 \times 10^{2}$ & - & $4 \times 10^{2}$ \\
\hline Cunninghamella echinulata var. echinulata (Thaxt.) Thaxt. ex Blakeslee & $7.4 \times 10^{3}$ & $3 \times 10^{3}$ & $8 \times 10^{2}$ & $1.12 \times 10^{4}$ \\
\hline C. echinulata var. verticillata (F.S. Paine) R.Y. Zheng \& G.Q. Chen & $3.6 \times 10^{3}$ & - & - & $3.6 \times 10^{3}$ \\
\hline C. elegans Lendn & - & $6 \times 10^{2}$ & $8 \times 10^{2}$ & $1.4 \times 10^{3}$ \\
\hline C. phaeospora Boedijn & $1.1 \times 10^{4}$ & - & $2 \times 10^{2}$ & $1.12 \times 10^{4}$ \\
\hline Fennellomyces heterothallicus P.C. Misra, N.N. Gupta \& Lata & - & $4 \times 10^{2}$ & - & $4 \times 10^{2}$ \\
\hline Lichtheimia corymbifera (Cohn) Vuill. & - & $2 \times 10^{2}$ & - & $2 \times 10^{2}$ \\
\hline L. hyalospora (Saito) Kerst. Hoffm., Walther \& K. Voigt & $1.3 \times 10^{4}$ & $2 \times 10^{2}$ & $4 \times 10^{2}$ & $1.36 \times 10^{4}$ \\
\hline Mucor luteus Linnem. ex Wrzosek & $8 \times 10^{2}$ & - & - & $8 \times 10^{2}$ \\
\hline M. prayagensis B.S. Mehrotra \& Nand ex Schipper & $8 \times 10^{2}$ & - & - & $8 \times 10^{2}$ \\
\hline M. racemosus f. chibinensis (Neophyt.) Schipper & - & - & $2 \times 10^{2}$ & $2 \times 10^{2}$ \\
\hline M. subtilissimus Oudem. & $2 \times 10^{2}$ & - & - & $2 \times 10^{2}$ \\
\hline Mycotypha microspora Fenner & - & - & $4 \times 10^{2}$ & $4 \times 10^{2}$ \\
\hline Rhizopus arrhizus var. arrhizus A. Fisch & - & $6 \times 10^{2}$ & $3 \times 10^{3}$ & $3.6 \times 10^{3}$ \\
\hline R. microsporus var. chinensis (Saito) Schipper \& Stalpers & - & $8 \times 10^{2}$ & $8 \times 10^{2}$ & $1.6 \times 10^{3}$ \\
\hline R. microsporus var. microsporus Tiegh. & - & $1 \times 10^{3}$ & $9.4 \times 10^{3}$ & $1.04 \times 10^{4}$ \\
\hline R. stolonifer (Ehrenb.) Vuill. & - & $4 \times 10^{2}$ & - & $4 \times 10^{2}$ \\
\hline Syncephalastrum racemosum Cohn ex J. Schröt & - & $6 \times 10^{2}$ & $4 \times 10^{2}$ & $1 \times 10^{3}$ \\
\hline Total & $6.84 \times 10^{4}$ & $8.2 \times 10^{3}$ & $1.64 \times 10^{4}$ & $9.3 \times 10^{4}$ \\
\hline Species richness & 8 & 11 & 10 & \\
\hline
\end{tabular}

BSF = Belém de São Francisco; PC = preserved Caatinga; LDD = Low degree of desertification; $\mathrm{SD}=$ severe desertification.

observed between Belém de São Francisco and Triunfo $(31.58 \%)$ and Cabrobó and Triunfo (20\%). The ANOSIM "one-way" showed significant differences on composition of Mucorales between samples from Triunfo and Belém de São Francisco $\left(\mathrm{R}_{\text {global }}=0.75 ; \mathrm{p}=0.029\right.$; number of permutations $=35)$; Triunfo and Cabrobó $\left(\mathrm{R}_{\text {global }}=0.651\right.$; $p=0.029$; number of permutations $=35$ ). However, the differences were not significant when comparing soils from Cabrobó and Belém de São Francisco $\left(\mathrm{R}_{\text {global }}=0.266\right.$; $\mathrm{p}=0.057$; number of permutations $=35$ ).

\section{Discussion}

The results of this manuscript increase the knowledge about diversity of Mucorales in soils of Caatinga. To date, there are no references regarding ecological studies of Mucorales from soils of semiarid regions outside Brazil, and in this country, only 13 taxa of Mucorales have been reported from Caatinga soil (Santiago, 2012). Absidia cylindrospora, $C$. elegans, $L$. hyalospora (as $A$. blakesleeana), $R$. arrhizus var. arrhizus (as $R$. oryzae) and $S$. racemosum were cited from the Caatinga soil of Jaguararí - Bahia (Santiago and Souza-Motta, 2006); Rhizopus microsporus var. microsporus and $R$. microsporus var. chinensis were reported in Serra Talhada and Canindé de São Francisco - Pernambuco (Cavalcanti et al., 2006; Tru- fem et al., 2006). Therefore, the other 11 taxa reported here are first records for Caatinga. More recently, a new parasitic zygomycetes (Zoopagales), Syncephalis aggregata A.L. Santiago \& Benny was isolated from soil in TriunfoPE (Santiago et al., 2011a), contributing to the knowledge of zygomycetes distribution in this ecosystem. Most of the genera and species identified in this study were isolated from soil in different ecosystems, both within Brazil and abroad. In Brazil, A. cylindrospora was isolated from soil in São Paulo, Bahia and Maranhão (Lira, 1971; SchoenleinCrusius et al., 1996; de Souza et al., 2008); R. arrhizus var. arrhizus was reported (some as R. oryzae) in Canindé de São Francisco (SE), Olho d'água do Casado (AL), Recife and São Paulo (Trufem, 1981a; Cavalcanti et al., 2006; de Souza et al., 2008; Santiago et al., 2011b); C. elegans was isolated from soil in Canindé de São Francisco, Olho d'água do Casado, Piranhas (AL) (Cavalcanti et al., 2006) and in São Paulo (Trufem, 1981b), and C. phaeospora was cited in Maranhão, São Paulo and Pernambuco (Upadhyay, 1970; de Souza et al., 2008; Santiago et al., 2011b). Mucor luteus (as M. hiemalis f. luteus) and M. prayagensis were only reported in São Paulo (Schoenlein-Crusius et al., 2006; de Souza et al., 2008). Apophysomyces elegans and Mycotypha microspora were reported as new to Brazil (Santiago and Maia, 2010). 
Table 2 - Relative abundance and frequency of occurrence of Mucorales in soils from Triunfo, Cabrobó and Belém de São Francisco.

\begin{tabular}{lcc}
\hline Mucorales & $\begin{array}{c}\text { Relative } \\
\text { abundance }\end{array}$ & $\begin{array}{c}\text { Frequency of } \\
\text { occurrence }\end{array}$ \\
\hline $\begin{array}{l}\text { Absidia cylindrospora var. } \\
\text { cylindrospora }\end{array}$ & $1.04 \%$ & $7.41 \%$ \\
Apophysomyces elegans & $0.10 \%$ & $0.93 \%$ \\
Cunninghamella echinulata var. & $2.77 \%$ & $9.26 \%$ \\
echinulata & & \\
C. echinulata var. verticillata & $0.48 \%$ & $1.85 \%$ \\
C. elegans & $0.35 \%$ & $4.63 \%$ \\
C.phaeospora & $2.77 \%$ & $1.85 \%$ \\
Fennellomyces heterothallicus & $0.10 \%$ & $1.85 \%$ \\
Lichtheimia hyalospora & $3.46 \%$ & $3.70 \%$ \\
L. corymbifera & $0.05 \%$ & $0.93 \%$ \\
Mucor luteus & $0.20 \%$ & $2.78 \%$ \\
M. prayagensis & $0.15 \%$ & $0.93 \%$ \\
M. racemosus f. chibinensis & $0.05 \%$ & $0.93 \%$ \\
M. subtilissimus & $0.05 \%$ & $0.93 \%$ \\
Mycotypha microspora & $0.10 \%$ & $0.93 \%$ \\
Rhizopus arrhizus var. arrhizus & $0.89 \%$ & $7.41 \%$ \\
R. microsporus var. microsporus & $0.57 \%$ & $10.19 \%$ \\
R. microsporus var. chinensis & $0.40 \%$ & $3.70 \%$ \\
R. stolonifer & $0.05 \%$ & $0.93 \%$ \\
Syncephalastrum racemosum & $0.20 \%$ & $1.85 \%$ \\
\hline
\end{tabular}

Among all taxa, only L. hyalospora was abundant, while $C$. echinulata var. echinulata and $C$. phaeospora were common. The majority of Mucorales showed rare distribution. With the exception of $F$. heterotallicus, all of these species have been previously reported in soil samples. Curiously, the four known species of Fennellomyces $[F$. linderi (Hesselt. \& Fennell) Benny \& R.K. Benj., F. heterothallicus, F. verticillatus J.H. Mirza, S.M. Khan, S. Begum \& Shagufta and F. gigacellularis J.H. Mirza, S.M. Khan, S. Begum \& Shagufta], were isolated only from animal dung, particularly rodents (Benny and Benjamin, 1975). Thus, this represents the first record of the genus in soil. Considering that dung is commonly in contact to soil, it is possible that the fungus had been isolated as a soil contaminant. Specimens of Cunninghamella, Mucor and Rhizopus are common soil inhabitants (Domsch et al., 1993).

Absidia cylindrospora var. cylindrospora, $C$. echinulata var. echinulata, $R$. arrhizus var. arrhizus and $R$. microsporus var. microsporus were the most frequently found in all three areas. Generally, in a community, very few taxa have high frequencies of occurrence, while the majority present low frequencies (Richardson, 2001; Nyberg and Persson, 2002). These observations were based on studies with coprophilous fungi, which display different behavior in relation to soil fungi. Generally, herbivorous dung is very rich in nutrients, minerals and red blood cells from the rumen, making it rich and favorable for fungal growth, including the Mucorales (Dix and Webster, 1995). However, the same was observed in this work, considering that only four species presented high frequency of occurrence $(>7 \%)$. Statistical analysis showed no differences in species richness between the three areas, which indicates that apparently desertification, climate and altitude are not affecting the number of Mucorales species. However, the community structure of Mucorales was different when comparing Triunfo to the other two areas which did not differ between them. Corroborating these results, the similarity studies highlighted a greater similarity between the Mucorales from soil from Belém de São Francisco and that of Cabrobó. This was expected since the area of Triunfo is quite different from the other two in terms of altitude and climate (Ministério das Minas e Energia, 2005a, 2005b, 2005 c). Thus, these differences make it difficult to determine whether the variations in the structure of the Mucorales community between Triunfo and the other areas reflect or not the impact of desertification. Apparently, in Triunfo the general conditions are more suitable for development of some Mucorales species. According to Bills et al. (2004), the heterogeneity of micro-habitats, competition within and between specific types of organic matter present in the substrate, temporal changes in climate and vegetation and the physiology of the fungi are all important factors to consider. It is possible that with more data the statistical analysis would present other values for richness and diversity. This manuscript reports the occurrence of 17 species and six varieties of Mucorales from semiarid areas of Northeast Brazil. Eleven taxa are registered for the first time in this ecosystem, while $F$. heterothallicus is reported for the first time in Brazil.

\section{Acknowledgments}

The authors are grateful to the Fundação de Amparo à Ciência e Tecnologia do Estado de Pernambuco (FACEPE) for providing a post-doc fellowship to A.Santiago and to the Conselho Nacional de Desenvolvimento Científico e Tecnológico (CNPq - Protax Proc. 562.330/2010-0; INCT-Herbário Virtual Proc. 573.883/2008-4; Sisbiota Proc. 563.342/2010-2; PQ Proc.302.416/2010-2) for a research fellowship to L.C.Maia and research grants.

\section{References}

Alastruey-Izquierdo A, Hoffmann K, de Hoog GS, RodriguezTudela JL, Voigt K, Bibashi E, Walther G (2010) Species Recognition and Clinical Relevance of the Zygomycetous genus Lichtheimia (syn. Absidia Pro Parte, Mycocladus). J Clin Microbiol 48:2154-2170.

Alves MH, Trufem SFB, Milanez AI (2002) Táxons de Mucor Fresen (Zygomycota) em fezes de herbívoros, Recife, PE, Brasil. Rev Bras Bot 25:147-160. 
Benny GL (2008) The methods used by Dr. R. K. Benjamin, and other mycologists to isolate Zygomycetes. Aliso 26:37-61.

Benny GL (2009) Zygomycetes. Available at http://www.zygomycetes.org. Accessed March 23, 2012.

Benny GL, Benjamin RK (1975) Observations on Thamnidiaceae (Mucorales). New taxa, new combinations, and notes on selected species. Aliso 8:301-351.

Bills GF, Christensen M, Powell M, Thorn G (2004) Saprobic soil fungi. In: Mueller GM, Bills GF, Foster MS (eds). Biodiversity of Fungi, Inventory and Monitoring Methods. Elsevier Academic Press, San Diego, pp 273-294.

Brower JE, Zar JH, Von Ende CN (1990) Field and Laboratory Methods for General Ecology. $3^{\text {rd }}$ edition. McGraw-Hill, Dubuque, 237 pp.

Cavalcanti MAQ, de Oliveira LG, Fernandes MJ, Lima DM (2006). Fungos filamentosos isolados do solo em municípios da região Xingó, Brasil. Acta Bot Bras 20:831-837.

Clarke KR, Warwick RM (1994) Change in Marine Communities - An Approach to Statistical Analysis and Interpretation. Plymouth Marine Laboratory, Plymouth, 144 pp.

de Souza JI, Schoenlein-Crusius IL, Oliveira LHS (2008) Selected species of Mucorales from soil contaminated with toxic metals in São Paulo State, Brazil. Mycotaxon 106:273-288.

Dix NJ, Webster J (1995) Fungal Ecology. Chapman \& Hall, London, 549 pp.

Domsch KH, Gams W, Anderson TH (1993) Compendium of Soil Fungi. Vol. 1. Academic Press, San Francisco, 377 pp.

Ferraz EMN, Rodal MJN, Sampaio EVSB, Pereira RCA (1998) Composição florística em trechos de vegetação de caatinga e brejo de altitude na região do Vale do Pajeú, Pernambuco. Rev Bras Bot 21:7-15.

Hesseltine CW, Fennel DI (1995) The genus Circinella. Mycologia 7:193-211.

Hibbett DS, Binder M, Bischoff JF, Blackwell M, Cannon PF, Eriksson OE, Huhndorf S, James T, Kirk PM, Lücking R, Lumbsch HT, Lutzoni F, Matheny PB, McLaughlin DJ, Powell MJ, Redhead S, Schoch CL, Spatafora JW, Stalpers JA, Vilgalys R, Aime MC, Aptroot A, Bauer R, Begerow D, Benny GL, Castlebury LA, Crous PW, Dai YC, Gams W, Geiser DM, Griffith GW, Gueidan C, Hawksworth DL, Hestmark G, Hosaka K, Humber RA, Hyde KD, Ironside JE, Kõljalg U, Kurtzman CP, Larsson KH, Lichtwardt R, Longcore J, Miadlikowska J, Miller A, Moncalvo JM, MozleyStandridge S, Oberwinkler F, Parmasto E, Reeb V, Rogers JD, Roux C, Ryvarden L, Sampaio JP, Schüßler A, Sugiyama J, Thorn RG, Tibell L, Untereiner WA, Walker C, Wang Z, Weir A, Weiss M, White MM, Winka K, Yao YJ, Zhang N (2007) A higher-level phylogenetic classification of the fungi. Mycol Res 3:509-547.

Ho HM (2002) The merosporangifeorus fungi from Taiwan (II). Two new records of Syncephalis. Taiwania 47:37-42.

Kirk PM, Cannon PF, David JC, Stalpers JA (2008) Ainsworth \& Bisby's Dictionary of Fungi. $10^{\text {th }}$ ed. CABI Publishing, Surrey, $771 \mathrm{pp}$.

Lira NP (1971) Espécies de Absidia do solo do Maranhão. Bol Inst Micol Univ Rec 657:1-6.

Magnuson JK, Lasure LL (2004) Organic acid production by filamentous fungi. In: Tkacz JS, Lange L (eds) Advances in Fungal Biotechnology for Industry, Agriculture, and Medi- cine. Kluwer Academic/Plenum Publishers, New York, pp 307-340.

Misra PC, Srivastava KJ, Lata K (1979) Apophysomyces, a new genus of the Mucorales. Mycotaxon 8:377-382.

Ministério das Minas e Energia (2005a) Projeto cadastro de fontes de abastecimento por água subterrânea. Diagnóstico do $\mathrm{Mu}-$ nicípio de Cabrobó, Pernambuco. Companhia de Pesquisa de Recursos Minerais/ Programa de Desenvolvimento Energético dos Estados e Municípios, Recife, 11 pp.

Ministério das Minas e Energia (2005b) Projeto cadastro de fontes de abastecimento por água subterrânea. Diagnóstico do Município de Belém de São Francisco, Pernambuco. Companhia de Pesquisa de Recursos Minerais/ Programa de Desenvolvimento Energético dos Estados e Municípios, Recife, $11 \mathrm{pp}$.

Ministério das Minas e Energia (2005c) Projeto cadastro de fontes de abastecimento por água subterrânea. Diagnóstico do $\mathrm{Mu}-$ nicípio de Triunfo, Pernambuco. Companhia de Pesquisa de Recursos Minerais/ Programa de Desenvolvimento Energético dos Estados e Municípios, Recife, 11 pp.

Nout MJR, Kiers JL (2005) Tempe fermentation, innovation and functionality: Update into the third millennium. J Appl Microbiol 98:789-805

Nyberg Å, Persson IL (2002) Habitat differences of coprophilous fungi on moose dung. Mycol Res 106:1360-1366.

O’Donnell KL (1979) Zygomycetes in Culture. University of Georgia, Georgia, 257 pp.

Peet RK (1974) The measurement of species diversity. Ann Rev Ecol Syst 5:285-307.

Ribes JA, Vanover-Sams CL, Baker DJ (2000) Zygomycetes in human disease. Clin Microbiol Rev 13:236-301.

Riccardi CL, Bashore SL (2003) First checklist of macrofungi for the deep woods - All taxa biodiversity inventory, Hocking County, Ohio. Mycotaxon 86:210-250.

Richardson MJ (2001) Diversity and occurrence of coprophilous fungi. Mycol Res 105:387-402.

Sampaio EVSB, Sampaio Y, Vital T, Araújo SB, Sampaio GR (2003) Desertificação no Brasil - Conceitos, Núcleos e Tecnologias de Recuperação e Convivência. Editora Universitária UFPE, Recife, 202 pp.

Santiago ALCMA (2012) Mucorales. Lista de Espécies da Flora do Brasil. Jardim Botânico do Rio de Janeiro. http://floradobrasil.jbrj.gov.br/2012/FB120276.

Santiago ALCMA, Maia LC (2010) Two new records of Mucorales from the Brazilian semi-arid region. Mycotaxon 114:171-177.

Santiago ALCMA, Benny GL, Maia LC (2011a) Syncephalis aggregata, a new species from the semiarid region of Brazil. Mycologia 103:135-138.

Santiago ALCMA, Souza-Motta CM (2006) Mucorales isolados do solo de mineração de cobre e produção de amilase e inulinase. Acta Bot Bras 20:641-647.

Santiago ALCMA, Trufem SFB, Malosso E, Santos PJP, Cavalcanti MAQ (2011b) Zygomycetes from herbivore dung in the Ecological Reserve of Dois Irmãos, northeast Brazil. Braz J Microbiol 42:89-95.

Schipper MAA (1978) On certain species of Mucor with a key to all accepted species. Stud Mycol 17:1-69.

Schipper MAA, Samson RA (1994) Miscellaneous notes on Mucoraceae. Mycotaxon 50:475-491. 
Schnittler M, Stephenson SL (2000) Myxomycetes biodiversity in four different forest types in Costa Rica. Mycologia 92:626-637.

Schoenlein-Crusius IH, Milanez AI, Trufem SFB, Pires-Zottarelli CLA, Grandi RAP, Santos ML, Giustra KC (2006) Microscopic fungi in the Atlantic Rainforest in Cubatão, São Paulo, Brazil. Braz J Microbiol 37:267-275.

Schoenlein-Crusius IH, Trufem SFB, Malatinsky SMM, Ninomiya A, Antunes MFR (1996) Mucorales (Zygomycotina) from soil affected by excrement of birds in the "Parque Estadual das Fontes do Ipiranga”, São Paulo, Brazil. Rev Bras Bot 19:7-10.

Sorensen T (1978) A method of establishing groups of equal amplitude in plant sociology based on similarity of species content and its application to analysis of the vegetation on Danish commons. In: McIntosh RP (ed) Phytosociology Benchmark Papers in Ecology, Stroudsburg, pp 235-249.

Trufem SFB (1981a) Mucorales do Estado de São Paulo. 2. Gêneros Absidia van Tieghem, Gongronella Ribaldi e Rhizopus Ehrenberg. Rickia 9: 99-106.44.

Trufem, SFB (1981b) Mucorales do Estado de São Paulo. 3. Gêneros Circinella Van Tieghem \& Le Monnier e Cunninghamella Matruchot. Rickia 9:113-120.

Trufem SFB, Maia LC, Souza-Motta CM, Santiago ALCMA (2006) Filo Zygomycota. In: Giulietii AM, Queiroz LP, Gusmão LFP, Maia LC (eds) Diversidade e Caracterização dos Fungos do Semi-Árido Brasileiro. Vol. 2. Instituto do Milênio do Semi-árido, Recife, pp 97-107.

Turco RF, Kennedy AC, Jawson MD (1994) Microbial indicators of soil quality. In: Doran JW, Coleman DC, Bezdicek DF, Stewart BA (eds) Defining Soil Quality for a Sustainable
Environment. Soil Science Society of America, Madison, pp 73-89.

Upadhyay HP (1969) Soil fungi from North-East and North Brazil. VII. Nova Hedw 17:65-73.

Upadhyay, HP (1970) Soil fungi from North-East and North Brazil. VIII. Persoonia 6:111-117.

Viriato A, Trufem SFB (1985) Mucorales do Estado de São Paulo. 7. Espécies Merosporangiadas. Rickia 12:147-154.

Wekesa VW, Moraes GJ, Knapp M, Delalibera IJ (2007) Interactions of two natural enemies of Tetranychus evansi, the fungal pathogen Neozygites floridana (Zygomycetes, Entomophthorales) and the predatory mite, Phytoseiulus longipes (Acari, Phytoseiidae). Biol Control 41:408-414.

Yin PM, Yahiro K, Ishigaki T, Park Y, Okabe M (1998) L $(+)$-Lactic acid production by repeated batch culture of Rhizopus oryzae in air-lift bioreactor. J Ferm Bioeng 85:96100.

Zar JH (1996) Biostatistical Analysis, 3rd edition. Prentice-Hall, New Jersey, 662 pp.

Zafar S, Aqil F, Ahmad I (2007) Metal tolerance and biosorption potential of filamentous fungi isolated from metal contaminated agricultural soil. Biores Technol 98:2557-2561.

Zheng RY, Chen GQ (2001) A monograph of Cunninghamella. Mycotaxon 80:75.55.

Zheng RY, Chen GQ, Huang H, Liu XY (2007) A monograph of Rhizopus. Sydowia 59:273-372.

Zhou Y, Dominguez JM, Cao NJ, Du JX, Tsao GT (1999) Optimization of L-lactic acid production from glucose by Rhizopus oryzae ATCC 52311. Appl Biochem Biotechnol 77:401407.

All the content of the journal, except where otherwise noted, is licensed under a Creative Commons License CC BY-NC. 